\title{
Heterosis, Combining Ability and Gene Action for Yield in Bottle Gourd
}

\author{
Akm Quamruzzaman ${ }^{1 *}$, M. M. R. Salim¹, L. Akhter'1, M. M. Rahman², M. A. Z. Chowdhury² \\ ${ }^{1}$ Olericulture Division, Horticulture Research Centre, Bangladesh Agricultural Research Institute, Gazipur, Bangladesh \\ ${ }^{2}$ Bangladesh Agricultural Research Council, Farmgate, Dhaka, Bangladesh \\ Email: *akmqzs@gmail.com
}

How to cite this paper: Quamruzzaman, A., Salim, M.R.M., Akhter, L., Rahman, M.M. and Chowdhury, M.A.Z. (2020) Heterosis, Combining Ability and Gene Action for Yield in Bottle Gourd. American Journal of Plant Sciences, 11, 642-652. https://doi.org/10.4236/ajps.2020.115048

Received: April 4, 2020

Accepted: May 12, 2020

Published: May 15, 2020

Copyright $\odot 2020$ by author(s) and Scientific Research Publishing Inc. This work is licensed under the Creative Commons Attribution International License (CC BY 4.0).

http://creativecommons.org/licenses/by/4.0/

\begin{abstract}
The experiment was conducted at the experimental field of Olericulture Division, Horticulture Research Centre (HRC), Bangladesh Agricultural Research Institute (BARI), Gazipur, Bangladesh during the winter season of 2018-2019 to study the genetic architecture of yield in a seven parent half diallel cross of bottle gourd. The values of mean square for GCA (general combining ability) and SCA (specific combining ability) were highly significant which suggested the presence of both additive and non-additive genetic variance in the population. But the higher magnitude of GCA compared to SCA indicated predominance of additive genetic variance. In most of the cases, the cross between poor and poor parents showed positive SCA effect for fruit yield, which indicated the higher yield. The estimates of significant positive better parent heterosis ranged from 6.27 to 49.72 percent. Analysis of genetic components of variation suggested that additive components were more important in the inheritance of fruit yield. This character was observed being controlled by two to three pairs of genes or groups of genes. Narrow sense heritability was 23 percent indicating probability of selection in generations. The graphical analysis also indicated wide genetic diversity among the parents.
\end{abstract}

\section{Keywords}

Bottle Gourd, Combining Ability, Heterosis, Genetic Architecture, Additive and Non-Additive Gene Actions

\section{Introduction}

Bottle gourd [Lagenaria siceraria (Mol.) Stand.] originated in Africa and from there, it spread over the world [1]. At present, it is grown in many countries including Bangladesh, India, Malaysia, Indonesia, Japan, China, The Philippines, 
Taiwan, Thailand, South Africa and Sudan [2]. Bottle gourd fruits are used as cooked vegetables. Its leaves and tender stems are used as delicious and nutritious vegetables. It is reported as an easily digestible vegetable which keeps the body cool and prevents constipation [3]. Each $100 \mathrm{~g}$ bottle gourd contains protein $1.1 \mathrm{~g}$, carbohydrate $15.1 \mathrm{~g}$, fat $0.1 \mathrm{~g}$, minerals $0.6 \mathrm{~g}$, and several vitamins [4].

Bottle gourd is a popular winter vegetable in Bangladesh. The climatic condition of winter in Bangladesh favours better growth and yield of bottle gourd but hot and humid summer and summer rainy season gives poor yield. The average day temperature of $20^{\circ} \mathrm{C}-27^{\circ} \mathrm{C}$ with lower night temperature of $18^{\circ} \mathrm{C}-23^{\circ} \mathrm{C}$ is optimum for growth and fruiting. Anthesis of flower in different cultivars is influenced by both temperature and rainfall. Bottle gourd is widely cultivated throughout the country. Its cultivation and uses are wide in winter season but nowadays it is cultivating during summer and rainy season. At present, the acreage and annual production of bottle gourd are 7217 ha and 85,267 tons respectively in Bangladesh with an average yield of 11.81 tons per hectare [5], which is very low compared to other countries. Hybrid varieties may play a vital role in satisfying the interest of producers and consumers. The identification and utilization of the most heterotic and useful crosses are very important in hybrid approach to make the commercial cultivation of hybrid beneficial [6]. So a wellplanned and dynamic bottle gourd breeding research programme is needed to meet the required demand of bottle gourd production.

The understanding of the nature and magnitude of gene action is an important factor in developing an effective breeding programme. The diallel analysis provides an efficient means of rapidly obtaining an overall picture of the genetic control of a character in a set of parents in the early generations. The analysis of combining ability helps in selecting suitable genotypes as parents for hybridization and crosses for characterizing the nature and magnitude of gene action involved in quantitative traits [7]. The use of contrasted lines in breeding programmes could contribute to create high yield varieties [8]. On the other hand, plant selection for high yield can be effective only if the variables under selection have high heritability values [9]. In Bangladesh context, the information on this aspect of bottle gourd is not sufficient. This study would be very important in developing hybrid varieties for Bangladesh conditions. Therefore, the present investigation was undertaken to investigate the genetic architecture of yield in bottle gourd.

\section{Materials and Methods}

The experiment was conducted at the Olericulture Division of Horticulture Research Centre, Bangladesh Agricultural Research Institute (BARI) during 2018-2019 with twenty one cross combinations viz., $\mathrm{P} 1 \times \mathrm{P} 2, \mathrm{P} 1 \times \mathrm{P} 3, \mathrm{P} 1 \times \mathrm{P} 4, \mathrm{P} 1 \times \mathrm{P} 5, \mathrm{P} 1$ $\times \mathrm{P} 6, \mathrm{P} 1 \times \mathrm{P} 7, \mathrm{P} 2 \times \mathrm{P} 3, \mathrm{P} 2 \times \mathrm{P} 4, \mathrm{P} 2 \times \mathrm{P} 5, \mathrm{P} 2 \times \mathrm{P} 6, \mathrm{P} 2 \times \mathrm{P} 7, \mathrm{P} 3 \times \mathrm{P} 4, \mathrm{P} 3 \times \mathrm{P} 5, \mathrm{P} 3$ $\times \mathrm{P} 6, \mathrm{P} 3 \times \mathrm{P} 7, \mathrm{P} 4 \times \mathrm{P} 5, \mathrm{P} 4 \times \mathrm{P} 6, \mathrm{P} \times \mathrm{P} 7, \mathrm{P} 5 \times \mathrm{P} 6, \mathrm{P} 5 \times \mathrm{P} 7$ and $\mathrm{P} 6 \times \mathrm{P} 7$ along with seven parents viz., P1 = LS 14, P2 = LS 01, P3 = LS 02, P4 = LS 03, P5 = LS 04, P6 = LS 07, P7 = LS 09 of bottle gourd. The experimental field was at 
23.9920 ${ }^{\circ} \mathrm{N}$ Latitude and $90.4125^{\circ} \mathrm{E}$ Longitudes having an elevation of $8.2 \mathrm{~m}$ from sea level under agro-ecological zone (AEZ) 28 [10]. The experimental site is situated in the sub-tropical climatic zone and characterized by scanty rainfall during the experimental time. The average minimum and maximum temperature were $18.37^{\circ} \mathrm{C}$ and $29.37^{\circ} \mathrm{C}$ and the average relative humidity varied from $55.55 \%$ to $75.70 \%$. The soil of the experimental field was sandy clay loam in texture having a $\mathrm{pH}$ range around 6.0. The seeds of this germplasm were sown on the seedbed on 05 October, 2018. Twenty days old seedlings were transplanted in the main field on 25 October, 2018. The experiment was laid out in a Randomized Complete Block design with three replications. The unit plot size was 10.0 $\times 2.0 \mathrm{~m}$ maintaining $2.0 \times 2.5 \mathrm{~m}$ spacing and $0.5 \mathrm{~m}$ drain. The land was fertilized with organic manure, N, P, K, S, B and Zn @ 10,000, 80, 45, 88, 25, 1.8 and 4.5 $\mathrm{kg} / \mathrm{ha}$, respectively. Half of organic manure and all of $\mathrm{S}, \mathrm{Zn}$ and $\mathrm{B}$ each of $\mathrm{P}$ and $\mathrm{K} @ 30 \mathrm{~kg} / \mathrm{ha}$ will be applied during final land preparation. Rest of organic manure and P and K@15 kg/ha will be applied as basal in pit. Rest of $\mathrm{N}$ and $\mathrm{K}$ will be applied after 20 days of transplanting in 4 equal installments at 20 days interval starting. The intercultural operations (weeding and irrigation etc.) were done as and when necessary. Three plants were selected randomly from each unit plot. Data on yield (ton/hectare) was recorded from three randomly selected plants per entry per replication.

\subsection{Statistical and Biometrical Analysis}

In the analysis of variance (ANOVA) the $\mathrm{F}$ test was used at the $5 \%$ and $1 \%$ levels of probability. The trait means were compared by the Tukey test at the $5 \%$ level of probability. The ANOVA for the experiment (RCBD) was estimated according to [11] procedure. The combining ability analysis for studied traits was carried out using method 2 of model 1 of [12], where parents and $F_{1}$ 's were included under the experiment excluding reciprocals.

Griffing's Method 2 and model 1 is as follows:

$$
X_{i j}=u+g_{i}+g_{j}+s_{i j}+(1 / b)^{k} e_{i j k},
$$

where $u=$ the population mean; $g_{i}=$ the general combining ability effect of the ith parent; $g_{j}=$ the general combining ability effect of the jth parent; $s_{i j}=$ the specific combining ability effect of the cross between $i$ th and $j$ th parents such that $s_{i j}$ $=s_{j i} ; e_{i j k}=$ the environmental effect associated with $i j k$ th observation.

Thus the experimental mccaterial comprises of $n(n+1) / 2$ genotypes through half diallel mating i.e. 28 genotypes (7 parents and 21 its $F_{1}$ (hybrids). The genetic components of variation were calculated according to Griffing's numerical approach and graphical analysis (Wr-Vr graph) given by [13] [14] [15].

\subsection{Estimates of GCA and SCA Effects}

The GCA and SCA effects were estimated according to [16] by the following formula: 


$$
\begin{gathered}
\text { GCA effects }\left(G_{i}\right)=\frac{1}{n+2} \sum\left[\left(Y_{i .}+Y_{i i}\right)-\frac{2}{n}\left(Y_{. .}\right)\right] \text {Restricted to } \sum_{i}^{n} g_{i}=0 \\
\operatorname{SCA} \operatorname{effects}\left(S_{i j}\right)=Y_{i j}-\frac{1}{n+2}\left[Y_{i .}-Y_{i i}+Y_{j .}+Y_{j j}\right]+\frac{2}{(n+1)(n+2)} Y_{i i}(i<j) .
\end{gathered}
$$

\subsection{Estimation of Heterosis}

For estimation of heterosis in each character the mean values of the $21 F_{1}$ 's have been compared with better parent $(B P)$ for heterobeltiosis. Percent heterosis was calculated as:

$$
H(B P)=\frac{\overline{F_{1}}-\overline{B P}}{\overline{B P}} \times 100
$$

The significance test for heterosis was done by using standard error of the value of better parent as:

$$
S E(B P)=\sqrt{3 / 2 \times M S E / r} .
$$

\subsection{Computation of Variance Components and Allied Parameters in $F_{1}$ Diallel}

Using the values of different statistics computed earlier the variance components and allied parameters as follows:

\begin{tabular}{cc}
\hline Variance components and allied parameters & Formulae \\
\hline$D$ (additive variance) & VOLO $-E$ \\
$F$ (mean Covariance of additive and dominance) & 2 VOLO -4 WOLOI $-2(n-2)(E / n)$ \\
$H_{1}$ (dominance variance) & VOLO -4 VL -4 WOLOI $-(3 n-2)(E / n)$ \\
$H_{2}$ (proportion of positive or negative genes) & $4 \mathrm{VILI}-4 \mathrm{VOL}-2 E$ \\
$h^{2}$ (dominance effect) & $4(\mathrm{MLI}-\mathrm{MLO})^{2}-4(n-1)\left(E / n^{2}\right)$ \\
$E$ (environmental variance) & $1 / r[\mathrm{RSS}+\mathrm{ESS}] /[(r-1)+(c-1)(r-1)]$ \\
Mean degree of dominance & $\sqrt{\left(H_{1} / D\right)}$ \\
Proportion of dominant genes \\
with positive or negative sign \\
Proportion of dominant and recessive genes \\
Number of gene blocks exhibiting dominance \\
$\mathrm{h}^{2}$ ns (heritability in narrow sense)
\end{tabular}

\section{Results and Discussion}

\subsection{Combining Ability}

A perusal of results of combining ability analysis indicated considerable nonadditive gene action in the inheritance of majority of the attributes studied. Hence, breeding methods involving selection, intermating of selects and reselection in 
segregating generations followed by pedigree method of breeding may help to improve the characters [7]. The values of mean sum of square for both GCA (general combining ability) and SCA (specific combining ability) were highly significant for yield in bottle gourd, which suggests the presence of both additive and non-additive genetic variance in the population (Table 1). But the higher magnitude of GCA compared to SCA indicated predominance of additive genetic variance. The GCA component is primarily a function of the additive genetic variance. GCA of parents plays a significant role in the choice of parents. A parent with higher positive significant GCA effects is considered as a good general combiner for yield. The magnitude and direction of the significant effects for the seven parents provide meaningful comparisons and would give indications to the future breeding programme.

\subsection{GCA Effect}

In the present study, parent P6 showed the greatest relative GCA effect $\left(1.75^{\star *}\right)$ followed by P1 $\left(1.07^{\star}\right)$, P2 and P7 $\left(1.06^{*}\right)$ for yield. Other parents showed either insignificant negative or significant negative GCA values. So, parents P6, P1, P2 and P7 were the best general combiners in crosses for the improvement of this trait. [17] [18] [19] reported that significant positive GCA effects obtained in bottle gourd. [19] also reported KBG-16 was the best general combiner for total yield per vine. While the parents P4 $\left(-2.74^{\star \star}\right)$, P3 and P5 $\left(-1.12^{\star}\right)$ were the poor combiner for yield in this study.

\subsection{SCA Effect}

Out of 21 cross combinations 14 crosses showed positive SCA effect for yield, among them 12 crosses exhibited significant positive SCA effect (Table 2). The highest positive significant SCA effects were shown by the hybrid P3 $\times$ P4 $\left(6.90^{\star *}\right)$ followed by P3 $\times$ P5 $\left(5.12^{* *}\right)$, P $4 \times$ P5 $\left(4.22^{\star *}\right)$, P4 $\times$ P7 $\left(3.57^{\star *}\right)$, P2 $\times$ P6 $\left(3.40^{\star *}\right)$ and P2 $\times$ P7 $\left(3.52^{\star *}\right)$. Thus P3 $\times$ P4 was the best combination (poor $\times$ poor combiner $)$ similar to other two hybrids $(\mathrm{P} 3 \times \mathrm{P} 5, \mathrm{P} 4 \times \mathrm{P} 5)$ for yield in bottle gourd. The other moderately higher values of positive SCA effect may be considered as good specific combiner viz., $\mathrm{P} 4 \times \mathrm{P} 7$ (poor $\times$ good combiner) and P2 $\times$ P6, P2 $\times$ P7 (good $\times$ good combiner) for fruit yield. [19] also found 3 hybrids viz., GH-10 $\times$ G-2, GH-9 $\times$ PSPL and GH-13 $\times$ G-2 exhibited significant

Table 1. Analysis of variance of general combining ability (GCA) and specific combining ability (SCA) and heterosis for fruit yield in bottle gourd.

\begin{tabular}{cccc}
\hline Source of variation & $\begin{array}{c}\text { Mean sum of square } \\
\text { for Combining ability }\end{array}$ & $\begin{array}{c}\text { Source of } \\
\text { variation }\end{array}$ & $\begin{array}{c}\text { Mean sum of square } \\
\text { for heterosis }\end{array}$ \\
\hline GCA & $23.75^{* *}$ & $\begin{array}{c}\text { Genotypes } \\
\left(\text { Parents \& } \mathrm{F}_{1} \mathrm{~s}\right)\end{array}$ & $63.97^{* *}$ \\
SCA & $20.62^{* *}$ & Replication & 6.72 \\
Error & 2.20 & Error & 6.60 \\
\hline
\end{tabular}

${ }^{\star}$ Significant at $5 \%$ level; ${ }^{* *}$ Significant at $1 \%$ level. 
Table 2. Combining ability effects (SCA and GCA) for yield of bottle gourd.

\begin{tabular}{|c|c|c|c|c|c|c|c|c|}
\hline Parent & & & & SCA & & & & GCA \\
\hline 오 $\sigma^{\top 7}$ & $\mathrm{P} 2$ & P2 & P3 & P4 & P5 & P6 & P7 & \\
\hline P1 & & -0.56 & $-2.60^{* *}$ & -1.89 & -0.68 & $3.40^{\star *}$ & $3.52^{* *}$ & $1.07^{\star}$ \\
\hline P2 & & & $1.99^{*}$ & 0.99 & $3.21^{\star *}$ & $-2.56^{\star *}$ & $3.25^{\star *}$ & $1.06^{\star}$ \\
\hline P3 & & & & $6.90^{* *}$ & $5.12^{* *}$ & $3.30^{* *}$ & -1.19 & -1.12 \\
\hline $\mathrm{P} 4$ & & & & & $4.22^{\star *}$ & $2.11^{\star}$ & $3.57^{\star *}$ & $-2.74^{* *}$ \\
\hline P5 & & & & & & 1.57 & -0.02 & $-1.12^{*}$ \\
\hline P6 & & & & & & & $3.17^{\star \star}$ & $1.75^{\star *}$ \\
\hline P7 & & & & & & & & $1.06^{*}$ \\
\hline S.E. (sij) & & & & 1.13 & & & & \\
\hline SE (sii-sjj) & & & & 1.56 & & & & \\
\hline SE (gi) & & & & & & & & 0.46 \\
\hline SE (gi-gj) & & & & & & & & 0.70 \\
\hline C.D Value (0.05) & & & & 1.98 & & & & 1.04 \\
\hline C.D Value (0.01) & & & & 2.49 & & & & 1.45 \\
\hline
\end{tabular}

${ }^{\star}$ Significant at $5 \%$ level; ${ }^{*}$ Significant at $1 \%$ level.

specific combining ability effects for fruit yield. [17] reported best SCA effect was obtained by 7 crosses and [18] reported best combiner was IC-92362 $\times$ Pusa Naveen in bottle gourd, which was in agreement with the present findings. [19] reported that the parents having poor GCA for certain traits when crossed with parents having high GCA for the same traits usually generated high positive SCA effect. Similar trends were also observed in the present study like P4 $\times$ P7. The parents like P4 having poor GCA for yield, when crossed with P7 having good GCA, for this character, gave higher positive SCA effects $(\mathrm{P} 4 \times \mathrm{P} 7)$. So a relationship seems to exist between general and specific combining ability effects, it would safely be assumed that good or poor GCA may provide good SCA combination.

\subsection{Heterosis}

Significant difference between genotype and replication was observed in ANOVA for fruit yield (Table 1). Among 21 combinations, 17 crosses showed significant positive better parent heterosis and it was ranged from $6.27 \%$ to $49.72 \%$. The highest significant positive better parent heterosis was exhibited for the hybrid P3 $\times$ P4 followed by P3 $\times$ P5 (44.97\%), P4 × P5 (39.47\%). While [20] reported the yield per plant of F1 hybrids L12 $\times$ T2 (13.80\%) and L9 $\times$ T1 (8.08\%) manifested heterosis over top parent. [21] stated the highest heterobeltiosis for yield was recorded in cross PSPL $\times$ NDBG-1 (106.85\%). [22] got 3 best F1 hybrids $(\mathrm{S} 46 \times \mathrm{S} 54, \mathrm{~S} 10 \times \mathrm{S} 52-7$ and S54 $\times$ S52-7) showed 84.5\%, 80.5\% and 80\% heterosis, respectively, for yield over the best parental line, S41. [21] stated three best 
performing F1 hybrids LA-46 $\times$ LA-99, LA-12 $\times$ LA-76 and LA-32 $\times$ LA-37 also showed 51.8 and 125.9, 81.8 and 121.1 and 99.1 and $200.1 \%$ higher yield over the better parent in Kharif and summer seasons, respectively. [22] reported the best performing hybrids for yield were S36-1 $\times$ NC59812-1 and S39-1 $\times$ S1-3, with $76.4 \%$ and $58.1 \%$ heterosis over better parents, respectively. For fruit yield the hybrids ABGS11-23 $\times$ DBG-5, ABG- $1 \times$ Arka Bahar and DBG- $6 \times$ DBG 5 recorded the highest estimates of heterosis over standard check [6]. The yield per plant exhibited appreciably high amount of heterosis over the better parent, top parent and commercial control [24]. These were in agreement with the present findings (Table 3).

\subsection{Genetic Components of Variation}

The components of variation along with the derived genetic ratios for fruit yield (Table 4) showed that the $D$ and $H$ components, which measure additive and dominance variation, respectively were significant. This indicated the importance of both additive and dominance components for the inheritance of all the genotypes in bottle gourd. However, the magnitude of dominance was higher than the additive component. These results agree with that reported by [25]. The $\mathrm{H}_{2}$ representing dominance deviation due to relative frequency of positive and negative genes was significant. The proportion of positive effects as indicated by $F$ value was non-significant for fruit yield, suggesting greater frequency of dominant alleles governing this character. The net dominance effect, obtained by

Table 3. Mean performance and percent heterosis over better parent for fruit yield in bottle gourd.

\begin{tabular}{|c|c|c|c|c|c|}
\hline Cross & $\begin{array}{c}\text { Mean } \\
\text { performance }\end{array}$ & $\begin{array}{c}\text { Better } \\
\text { parent } \\
\text { heterosis }\end{array}$ & Cross & $\begin{array}{c}\text { Mean } \\
\text { performance }\end{array}$ & $\begin{array}{c}\text { Better } \\
\text { parent } \\
\text { heterosis }\end{array}$ \\
\hline $\mathrm{P} 1 \times \mathrm{P} 2$ & 30.4 & 3.41 & $\mathrm{P} 3 \times \mathrm{P} 4$ & 39.5 & $49.72^{\star *}$ \\
\hline $\mathrm{P} 1 \times \mathrm{P} 3$ & 28.6 & -0.35 & $\mathrm{P} 3 \times \mathrm{P} 5$ & 38.2 & $44.97^{\star *}$ \\
\hline $\mathrm{P} 1 \times \mathrm{P} 4$ & 29.0 & 1.05 & $\mathrm{P} 3 \times \mathrm{P} 6$ & 39.8 & $15.89^{\star *}$ \\
\hline $\mathrm{P} 1 \times \mathrm{P} 5$ & 30.5 & $6.27^{\star \star}$ & $\mathrm{P} 3 \times \mathrm{P} 7$ & 32.9 & $13.74^{\star *}$ \\
\hline $\mathrm{P} 1 \times \mathrm{P} 6$ & 38.0 & $10.64^{\star \star}$ & $\mathrm{P} 4 \times \mathrm{P} 5$ & 36.8 & $39.47^{\star \star}$ \\
\hline $\mathrm{P} 1 \times \mathrm{P} 7$ & 35.7 & $23.42^{\star *}$ & $\mathrm{P} 4 \times \mathrm{P} 6$ & 38.0 & $10.79^{* *}$ \\
\hline $\mathrm{P} 2 \times \mathrm{P} 3$ & 34.8 & $18.57^{\star \star}$ & $\mathrm{P} 4 \times \mathrm{P} 7$ & 37.1 & $28.26^{\star *}$ \\
\hline $\mathrm{P} 2 \times \mathrm{P} 4$ & 33.3 & $13.29^{\star \star}$ & $\mathrm{P} 5 \times \mathrm{P} 6$ & 38.0 & $10.79^{\star *}$ \\
\hline $\mathrm{P} 2 \times \mathrm{P} 5$ & 36.0 & $22.66^{\star \star}$ & $\mathrm{P} 5 \times \mathrm{P} 7$ & 34.1 & $17.72^{\star \star}$ \\
\hline $\mathrm{P} 2 \times \mathrm{P} 6$ & 33.6 & -2.04 & $\mathrm{P} 6 \times \mathrm{P} 7$ & 40.6 & $18.37^{\star \star}$ \\
\hline $\mathrm{P} 2 \times \mathrm{P} 7$ & 37.1 & $26.24^{\star *}$ & & & \\
\hline S.E. & & 1.81 & S.E. & & 1.81 \\
\hline C.D Value (0.05) & & 3.71 & C.D Value (0.05) & & 3.71 \\
\hline C.D Value (0.01) & & 5.01 & C.D Value (0.01) & & 5.01 \\
\hline
\end{tabular}

${ }^{\star}$ Significant at $5 \%$ level, ${ }^{*}$ Significant at $1 \%$ level. 
Table 4. Estimates of genetic components of variation and their ratios for yield in bottle gourd.

\begin{tabular}{cccc}
\hline Source of variation & Fruit yield & Source of variation & Fruit yield \\
\hline$D$ & $8.56^{* *} \pm 3.20$ & $\left(H_{1} / D\right)^{1 / 2}$ & 2.80 \\
$H_{1}$ & $67.40^{* *} \pm 7.70$ & $H_{2} / 4 H_{1}$ & 0.21 \\
$H_{2}$ & $59.23^{* *} \pm 6.80$ & $\frac{\left(4 D H_{1}\right)^{1 / 2}+F}{\left(4 D H_{1}\right)^{1 / 2}-F}$ & 1.16 \\
$F$ & $3.62 \pm 7.67$ & $h^{2} / H_{2}$ & 2.40 \\
$h^{2}$ & $142.19^{* *} \pm 4.56$ & $h^{2}$ (narrow sense) & 0.23 \\
$E$ & $6.60^{* *} \pm 1.13$ & & \\
\hline
\end{tabular}

the estimate $h^{2}$ expressed as the algebraic sum over all loci in heterozygous condition in all crosses, was significant. This revealed that substantial contribution of dominance effects was due to heterogeneity of loci. The environmental component $E$ exhibited significant values, indicating influence of environmental factors in the expression. However, the magnitude of $\mathrm{E}$ was definitely lower due to no value than the respective value of $D$ and $H_{1}$. This also indicated that the characters were influenced less by the environment.

The average degree of dominance as indicated by the proportion $\left(H_{1} / D\right)^{1 / 2}$ was more than unity, suggesting that over dominance was operating in the expression for fruit yield of bottle gourd. [26] [27] also found over-dominance in graphic analysis. The ratio of $H_{2} / 4 H_{1}$ provides an estimate of the average frequency of positive and negative alleles in all the parents. A value of this ratio smaller than 0.25 studied suggested asymmetrical distribution of only the negative alleles. The ratio of $\left[\left(4 D H_{1}\right)^{1 / 2}+\mathrm{F} /\left(4 D H_{1}\right)^{1 / 2}-F\right]$ estimates the relative proportion of dominant and recessive alleles in the parents. In the present study the ratio for the yield was greater than unity, suggesting excess of dominant alleles and minority of recessive alleles i.e., asymmetrical distribution for dominant alleles in the parents. The ratio of $h^{2} / H_{2}$ estimates the number of gene or group of genes which control the character exhibiting the degree of dominance. The $h^{2} / H_{2}$ values for yield per plant were 2.40, indicated the involvement of 2 to 3 genes or gene groups in the inheritance of this character as per ratio which are responsible for genetically control. Heritability in narrow sense was higher for fruit yield, indicating that this character was highly heritable. These results agree with that reported by [25]. Predominance of non-additive gene action for number of seeds per fruit and hundred seed weight is evident from the higher estimate of SCA variance component than GCA variance component [28] [29].

\subsection{Graphical Analysis}

Graphical analysis of parent-offspring covariances (Wr) on array variances ( $\mathrm{Vr}$ ) is shown in Figure 1. It was observed from the $\mathrm{Wr} / \mathrm{Vr}$ graph that the slope of the regression line for fruit yield was significantly below $1.0(0.36 \pm 0.11)$, suggesting 


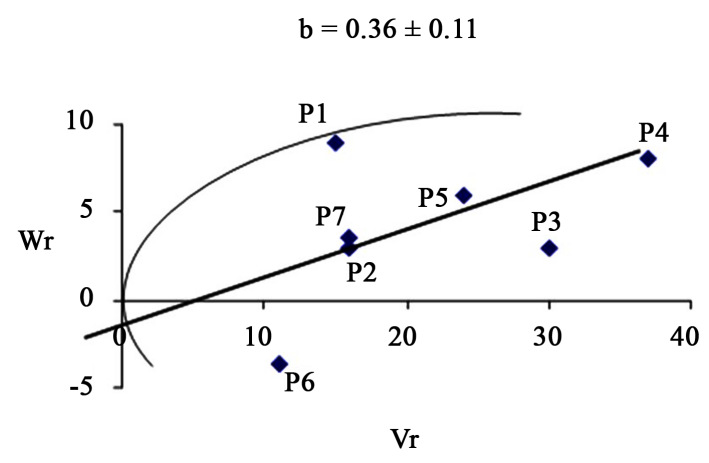

Figure 1. Wr, Vr regression and limiting parabola for fruit yield.

significant non-allelic interaction for this character. The regression line intersected the $\mathrm{Wr}$ axis below the origin, suggested over dominance in addition to the interaction.

In Figure 1, all the $\mathrm{Wr}, \mathrm{Vr}$ points fell within the boundary of the limiting parabola and the parents also clustered into three distinct groups on the regression line showing diversity in the parents for this trait. [30] reported the top five high yielding crosses showed overdominance for fruit yield per plant. The relative values of $\mathrm{Wr}$ and $\mathrm{Vr}$ showed that the parent P6 had the lowest value and hence contained the most dominant alleles while the parent $\mathrm{P} 4$ had the highest $\mathrm{Wr}, \mathrm{Vr}$ values and have the most recessive alleles. The other parents fell in between suggested that the equal frequency of dominant and recessive alleles. Similar findings were reported by [31] [32] in bean and [33] in eggplant.

\section{Conclusion}

In the present study, the parents, P6, P1, P2 and P7 were found to be good general combiners for yield and may be used in a breeding programme for developing high yielding varieties. The crosses, $\mathrm{P} 3 \times \mathrm{P} 4, \mathrm{P} 3 \times \mathrm{P} 5, \mathrm{P} 4 \times \mathrm{P} 5, \mathrm{P} 4 \times \mathrm{P} 7, \mathrm{P} 2 \times$ $\mathrm{P} 6$ and $\mathrm{P} 2 \times \mathrm{P} 7$ were found promising for high yielding. The both additive and dominance components of variation were important for the yield. The genetic components of variation analysis suggested that the excess of dominant alleles and a minority of recessive alleles i.e., presence of asymmetrical distribution for dominant alleles in the parents. Heritability in narrow sense indicated that this character was highly heritable. The yield was observed being controlled by two to three pairs of genes or groups of genes. The graphical analysis indicated wide genetic diversity among the parents.

\section{Conflicts of Interest}

The authors declare no conflicts of interest regarding the publication of this paper.

\section{References}

[1] Whitakar, T.W. and Davis, N.G. (1962) Cucurbits. Interscience Publishers Inc., New York, 75-76. 
[2] Yonernori, S. and Fujeda, K. (1985) Sex Expression in Bitter Gourd (Momordicacharantia L.). Science Bulletin, 32, 183-187.

[3] Seshadri, V.S. and Parthasarathy, V.A. (2002) Cucurbits. In: Bose, T.K., Kabir, J., Maity, T.K., Parthasarathy, V.A. and Som, M.G., Eds., Vegetable Crops, NayaPrakash, Calcutta, 493-648.

[4] Anonymous (2017) Year Book of Agricultural Statistics of Bangladesh 2016. Bangladesh Bureau of Statistics, Ministry of Planning, Government of Peoples Republic of Bangladesh, Dhaka, Bangladesh, 297.

[5] Doloi, N., Patel, J.N. and Acharya, R.R. (2018) Heterosis Studies in Bottle Gourd [Lagenariasiceraria (Mol) Standl]. Vegetos, 31, 1.

[6] Rani, K.U. and Reddy, E.N. (2017) Combining Ability Analysis for Yield and Its Components in Bottle Gourd. International Journal of Pure \& Applied Bioscience, 5, 809-817. https://doi.org/10.18782/2320-7051.5401

[7] Acquaah, G. (2007) Principles of Plant Breeding and Genetics. Blackwell Publishing, Malden, MA, $740 \mathrm{p}$.

[8] Akbar, M., Shakoor, M.S., Hussain, A. and Sarwar, M. (2008) Evaluation of Maize 3-Way Crosses through Genetic Variability, Broad Sense Heritability, Characters Association and Path Analysis. Journal of Agricultural Research, 46, 39-45.

[9] Anonymous (1995) Agro-Climatatrological Data. Agromet Division, Bangladesh Meteorological Department, Joydebpur, Gazipur, 35-65.

[10] Panse, V.G. and Shukhatme, P.V. (1967) Statistical Methods for Agriculture Workers. 2nd Edition, Indian Council of Agriculture Research, New Delhi.

[11] Griffing, B. (1956) Concept of General and Specific Combining Ability in Selection to Diallel Crossing Systems. Australian Journal of Biological Science, 9, 463-493. https://doi.org/10.1071/BI9560463

[12] Jinks, J.L. and Hayman, B.I. (1953) The Analysis of Diallel Crosses. Heredity, 10, 1-30. https://doi.org/10.1038/hdy.1956.1

[13] Hayman, B.I. (1954) The Theory and Analysis of Diallel Crosses. Genetics, 39, 789-809.

[14] Askel, R. and Johnson, L.P.V. (1963) Analysis of a Diallel Cross: $A$ Worked Example. Advance Frontier Plant Science, 2, 37-54.

[15] Sharma, J.R. (1998) Statistical and Biometrical Techniques in Plant Breeding. New Age International (P) Ltd., India, 432.

[16] Dubey, S.K. and Maurya I.B. (2006) Combining Ability Studies in Bottle Gourd [Lagenaria siceraria (L.) (Molina) Standl.]. Indian Journal Hortorticulture, 63, 178-181.

[17] Pal, S.N., Ram, D., Pal, A.K. and Singh, G. (2004) Combining Ability Studies for Certain Metric Traits in Bottle Gourd [Lagenaria siceraria (Mol.) Standl.]. Indian Journal Hortorticulture, 61, 46-50.

[18] Khan, N.I., Bajwa, M.A. and Asi, A.G. (1985) Combining Ability Study in a Diallel Cross of Five Wheat Varieties. Pakistan Journal of Agricultural Research, 6, 248-251.

[19] Sharma, N., Sharma, N.K., Malik, Y.S. and Sharma, N. (2002) Combining Ability in Long-Fruited Bottle Gourd. Haryana Journal of Horticultural Science, 31, 79-82.

[20] Sarvesh, K., Singh, S.P., Jaiswal, R.C. and Kumar, S. (1999) Heterosis Over mid and Top Parent under the Line X Tester Fashion in Bottle Gourd [Lagenaria siceraria (Mol.) Standl.]. Vegetable Science, 26, 30-32.

[21] Sarvesh, K., Singh, S.P., Singh, N.K. and Kumar, S. (1998) Line X Tester Analysis for Combining Ability and Heterosis in Bottle Gourd. Vegetable Science, 25, 78-80. 
[22] Janakiram, T. and Sirohi, P.S. (1992) Studies on Heterosis for Quantitative Characters in Bottle Gourd. Journal of Maharashtra Agriculture University, 17, 204-206.

[23] Rao, B.N., Rao, P.V. and Reddy, B.M. (2000) Heterosis in Ridge Gourd (Luffaacutangula (Roxb.) L.) Haryana Journal of Horticultural Science, 29, 96-98.

[24] Sirohi, P.S., Reddy, Y.S. and Behera, T.K. (2002) Heterosis for Yield and Its Attributing Traits in Pumpkin (Cucurbitamoschata Duch. ex Poir.). Vegetable Science, 29, 178-179.

[25] Yadav, I.S. and Yadava, T.P. (1996) Genetic Analysis and Combining Ability for Seed Yield Components in Toria (Brassica campestris L var. Toria). Journal of Oilseeds Research, 13, 84-87.

[26] Trivedi, H.B.P. (1980) Studies on Nature of Inheritance and Implication in Improvement of Oil Characteristic of Brassica juncea (Linn) Czem. \& Coss. Ph.D. Thesis, Indian Agricultural Research Institute, New Delhi.

[27] Trivedi, H.B.P. and Mukharjee, B.K. (1986) Genetic Parameters and Their Implications in Breeding High-Oil and Varieties of Indian Mustard. Indian Journal of Agriculture Science, 56, 10-14.

[28] Parvathi, L. (2002) Genetic Analysis of Yield and Yield Attributes in F2 Generation of 5 X 5 Diallel Set in Bottlegourd (Lagenaria siceraria (Mol.) Standl.). Ranga Agricultural University, Hyderabad.

[29] Sreevani, P.G. (2002) Heterosis and Combining Ability Studies in 5 X 5 Diallel of Bottlegourd (Lagenaria siceraria (Mol.) Standl.). Ranga Agricultural University, Hyderabad.

[30] Singh, S.N., Singh, N.D. and Hazarika, G.N. (1982) A Note on Degree of Dominance and Parental Mean Performance in Brinjal (Solanum melongena L.). Haryana Journal of Horticultural Science, 11, 146-148.

[31] Kabir, M.Y., Sultana, N., Rahman, M.M. and Mian, M.A.K. (2006) Genetic Analysis for Agronomic Characters in Lablab Bean (Lablab purpureus (L.) Sweet). Bangladesh Journal of Plant Breeding and Genetics, 19, 31-36.

[32] Islam, A.K.M.A., Jahan, M.M.A. and Newaz, M.A. (2006) Diallel Analysis for Gene Action in Dry Bean (Phaseolus vulgaris L.). Bangladesh Journal of Plant Breeding and Genetics, 19, 7-14.

[33] Quamruzzaman, A.K.M., Ahmad, S. and Moniruzzaman, M. (2008) Gene Action for Yield Components in Eggplant (Solanum melongena L.). Annals of Bangladesh Agriculture, 12, 93-96. 